\title{
THE ANIMAL PROBLEM
}

\section{Michele Beevors}

In 1995, Steve Baker wrote The Post-Modern Animal, addressing the then recent phenomena of a return of animal subjects to the world of art. Early Modernist art was largely devoid of animals; Franz Marc's horses and dogs, and Picasso's reference to himself as alternate manifestations of the bull and the monkey are exceptions that take opposing views on the idea of the representation of the animal in art. Marc was trying to capture something of the essence of the horse, and Picasso was using the commonly held beliefs about monkeys (naughty/rude) and bulls (virile) as an examination of self. If representations of the animal did not appear in Modern art unless it was as a disguise, it appeared everywhere in modern capitalism. The animal as material substance in the meat industry (and the pet food industry, who put the gelatine in silver gelatine photography) rose alongside. In advertising, animals appeared as the selling point of cars at one end (think of the brand Jaguar and the speed it implies) and, at the other, Louie the Fly as a popular brand of fly spray designed to kill poor Louie. In popular culture, the animal appeared from Disneyfied versions of rabbits, mice and deer, to the nature documentary where animal/camera nexus brings the violence of real life into the home.

Since Baker's text arrived, many discussions have evolved in the realms of cultural studies and art histories, about the role representations of animals play in displays of power, capitalism, colonial discourses, and art history. Recent development of issues-based art see the animal question become even more urgent. These ideas have seen young artists turning to this issue time and again over the unresolvable nature of the majority of the arguments, with multiple positions for and against representation. In 2019, the Dunedin School of Art hosted a one-day symposium to address some of these ideas. In this issue of Scope (Art \& Design): Animals at the Edge, some of the issues at stake with representing animals are addressed. The essays collected here consider different aspects of the animal problem, and fall into three distinct categories: representation, ethics, and the nexus between animals and environment. Each of these categories have fuzzy edges though as the terrain is definitely complex.

In his essay "Animals, De Anima, objet (petit) a. and the Anthropocene," David Green examines the animal from its first appearance on cave walls to stock footage gleaned from the internet and reformatted to give a skewed view of the violence of spear and camera alike. In his art work, Green examines the animal bodies inscribed as a desire to have. Like most things seen in this manner, it doesn't bode well for the animal.Viewed at this angle, desire is seen as a longing for what can never be again. Madison Kelly's text "Uncertain Observer" describes the problem of habitat (and loss) by avoiding direct and traditional approaches to representations of animals, turning instead to the animal's indexical trace in the interconnectedness of environment to modes of seeing. In "Not So Natural History: depicting the role of the Animal in Human Histories," Elaine Mitchell is concerned with the misrepresentations of species in early scientific illustration, examining the specimen cases of museum dioramas in dramatic water colours that pit the representation of the animal against imagined scenes of destruction.

Curator Emma Burns describes the Otago Museum as a library of life in "The Living Dead: The afterlives of Animals in Museums", bearing the historical weight of responsibility of colonial efforts to understand and know the living world. Nowadays, museums find they are caught between the worlds of science and research, education, entertainment and community access. The historical purpose of the museum, the collections, become springboards to informationcentred learning, to care for the environment and to protect the biodiversity of local species, serving as indicators of change and loss. Kari Schmidt's essay "Farmed Animals and the Law in New Zealand" is brimming with an enthusiasm 
for an update to legislation that is outdated in the care and welfare of farming practices in New Zealand. As the nature of farming moves from the home kill to industrial practices, the legislation falls far short of protecting its vulnerable species. Ethical considerations are also examined by Jenny Aimers and Peter Walker in "Animal Ethics in New Zealand Art: A Social Science Perspective" as they turn to the Dunedin Public Art Gallery collection, examining six specifically New Zealand Pākehā images, where the art work is judged to be fulfilling the criteria of an ethical post-humanist position, or not. An ethical turn is examined by Irena Kennedy in "Animals on Display:The Ethics of Keeping Animals," as her art works look at the problematics of breeding standards of kennel clubs and dog shows. The dog reflects the owner's style as an accessory. Kennedy's art work is informed by a stint working at La Sende Verde Animal Sanctuary in Bolivia, South America. The having and keeping of wild animals as pets, along with the illegal trade in exotic species, is born of the same kind of longing as the keeping of domestic species. The pet industries are called into question in Kennedy's art works. In her empty zoo, exhibited in Melbourne, all the artificial trappings of environment are enacted for a viewer (tyre swing, fake water fall, enrichment activities) but the presence of the animal is registered as a loss.

Pam McKinlay takes a poetic turn when looking at the art works of Kylie Matheson, whose small scale ceramic works invoke feelings of love and care - a childhood nostalgia for a world devoid of violence, a world where Beatrix Potter and AA Milne might have lived.

While the idea of a cat at a café is not so remarkable, taken to extreme lengths as a reason for tourism, it is explored in the text "Japanese Animal Tourism and the Kawaii (cute) Aesthetic" by Emily Crossley. Small cute creatures, bred for the purpose of fulfilling a need to cuddle something soft and furry, can be seen, in light of the Tiger King, to be immensely problematic. Informed by our need to mother, a cute neotinised baby orangutan or hedgehog fulfils this longing, but an unregulated industry can lead to inhuman treatment, miserable lives, and illegal deaths.

The deaths of animals, especially birds, from plastic in the ocean informs Tori Clearwater's work as an artist. Clearwater is concerned with the statistical information of the hyperobject of plastic pollution. In one of her schematic works, plastic tiles are melted into a screen that obscures the view; its colourful, up close always oily surface, reflects the light. The work reveals the way we take for granted the carelessness of generations of plastic consumers, and the death of sea life as the multi-coloured spectacle of advanced capitalism (e.g. the throw-away shopping bag). In "Human Nature," Clearwater asks, how does anthropomorphism effect how humans see nature in contemporary art?

In writing, as an art work, "Silent Spring to Climate Rebellion," Adrian Hall's personal history is turned to political action. Hall's writing is a call to arms - a provocation. Hall sees the interrelation of action and local environment echoed on the world stage, as Trump shuts down arguments of climate change and Thunberg dams us to a hell of our own making. Hall's art works can be read as quotation marks, beginning and ending the text. Turning upside down, long held beliefs, and calling for fresh eyes to really see things as they are, not as we imagine them to be. Bridie Lonie begins her work, "Solastalgia, Extinctions, the Chthulucene and the Symbiosphere" by focusing us on the word "solistalgia," which means distress at the environmental change perceived as negative. Coined by Glenn Albrecht, solistalgia is not just a sadness at the mess we are in, but an inability to get out of our own way, doomed to keep repeating the same mistakes, even though we know the consequences. All life becomes a trade-off. The chickens in your garden or the spiders - you choose. For my own part, in "Taxidermy", I wrote about the animal problem as it relates to taxidermies as sculpture, to pit an open reading of materiality against the decorative formalism of some contemporary artworks.

Most of the articles that appear in this issue were given as papers at the Animals at The Edge Symposium. The premise was to highlight some issues around representing animals and to give students a balanced view of the complexity of looking at animals. We asked for papers from local scientists involved with conservation efforts, from lawyers involved in legislation change and other educators in other institutions. As you can imagine the response was overwhelming and more than a one-day symposium could cope with. To the writers, we say thank you for your contribution. To Otago Polytechnic, we say thank you for recognising that this is something worth doing. To our readers, we say that we are not done here, because when we don't represent our most urgent thoughts, art becomes a hollow reflection of capital only, a super commodity about anything and nothing. 